\title{
Implementasi Sifat Nabi dalam Kepemimpinan Pendidikan di Sekolah Dasar
}

\author{
Muhammad Nasri Dini, Syamsul Bakri \\ UIN Raden Mas Said Surakarta \\ elnasri.ahmad@gmail.com
}

\section{Article History}

received 02/10/2021

\begin{abstract}
A leader must apply the knowledge of leadership in order to carry out his leadership well. One type of leadership in Islam is leadership based on the personality traits of the prophet. This study will describe how the implementation of prophetic traits in educational leadership in elementary schools. The research was conducted at SD Muhammadiyah Imam Syuhodo Sukoharjo. The method used in this research is a qualitative descriptive method with a case study research design. The resource person for this research is the principal of the school, teachers, employees and parents. The technique used in collecting data in this research is the technique of interview, observation, and documentation. Then the data obtained was then analyzed by data reduction techniques, data presentation, and data verification. The results of this study indicate that the mandatory traits of the Prophet Muhammad have been tried to be implemented by the school principal in educational leadership at SD Muhammadiyah Imam Syuhodo Sukoharjo. The characteristics of the Prophet are: sidiq (honest), amanah (trustworthy), tabligh (communicative) and fathanah (intelligent). The conclusion of this study is that the nature of the prophet has been implemented in SD Muhammadiyah Imam Syuhodo.
\end{abstract}

Keywords: Implementation, prophetic traits, educational leadership

\begin{abstract}
Abstrak
Seorang pemimpin harus menerapkan ilmu kepemimpinan agar dapat menjalankan kepemimpinannya tersebut dengan baik. Salah satu tipe kepemimpinan dalam Islam adalah kepemimpinan berbasis sifat-sifat kepribadian nabi. Penelitian ini akan mendeskripsikan bagaimana implementasi sifat-sifat nabi dalam kepemimpinan pendidikan di sekolah dasar. Penelitian dilakukan di SD Muhammadiyah Imam Syuhodo Sukoharjo. Metode yang digunakan dalam penelitian ini adalah metode deskriptif kualitatif dengan desain penelitian studi kasus. Narasumber penelitian ini adalah kepala sekolah, guru, karyawan dan orang tua siswa. Teknik yang digunakan dalam pengumpulan data pada penelitian ini adalah teknik wawancara, observasi, dan dokumentasi. Kemudian data yang diperoleh selanjutnya dianalisis dengan teknik reduksi data, penyajian data, dan verifikasi data. Hasil penelitian ini menunjukkan bahwa sifat-sifat wajib Nabi Muhammad sudah berusaha diimplementasikan oleh kepala sekolah dalam kepemimpinan pendidikan di SD Muhammadiyah Imam Syuhodo Sukoharjo. Adapun sifat-sifat Nabi tersebut yaitu: sidiq (jujur), amanah (terpercaya), tabligh (komunikatif) dan fathanah (cerdas). Kesimpulan dari penelitian ini bahwa sifat nabi sudah diimplementasikan di SD Muhammadiyah Imam Syuhodo.
\end{abstract}

Kata kunci: Implementasi, sifat nabi, kepemimpinan pendidikan 


\section{PENDAHULUAN}

Membicarakan tentang masalah kepemimpinan adalah suatu hal yang tidak akan pernah ada habisnya dan selalu menarik untuk dibahas. Karena berhasil atau tidaknya suatu organisasi dalam meraih tujuan akhir yang ingin dicapainya salah satu faktor paling penting yang dapat menentukan adalah kepemimpinan (Purwanto, 2019). Atas apa yang dipimpinnya tersebut seorang pemimpin pasti akan dimintai pertanggungjawaban. Di dunia ini pertanggungjawaban akan diminta oleh pihak-pihak yang berkepentingan, entah itu dari para anggota dari organisasi yang dipimpinnya, atau juga atasannya secara struktural dalam organisasi. Dan seorang pemimpin kelak di akhirat sebagai pertanggungjawaban paling akhir pasti juga akan menghadap dan ditanya oleh Tuhan tentang kepemimpinan yang telah dijalankannya semasa hidup di dunia.

Bahwa setiap manusia pada hakikatnya adalah seorang pemimpin, meskipun dalam lingkup yang kecil. Agar kehidupan yang dijalaninya mempunyai arah dan tujuan yang jelas, dalam space yang terkecil bahkan dia juga harus menjadi pemimpin bagi dirinya sendiri (Djunaedi, 2005). Salah satu tugas manusia adalah bahwa di pundaknya ada beban tanggung jawab yang harus dia pikul, tanggung jawab yang sebelumnya pernah juga ditawarkan kepada makhluk-makhluk Tuhan lainnya seperti langit, bumi, dan gunung, tetapi mereka semuanya tidak punya kemampuan untuk menerimanya dan merasa keberatan atas tanggung jawab tersebut. Setelah menjadi pemimpin bagi dirinya sendiri manusia juga menjadi pemimpin atas keluarga dan masyarakat (Bakar, 2014).

Seorang pemimpin yang bisa menjadi pengayom bagi bawahannya sangat dibutuhkan dalam sebuah organisasi. Agar segala proses pelaksanaan program kerja yang ingin untuk dicapai dapat lebih terarah dan terlaksana dengan baik sesuai dengan tujuan yang ada dan telah diprogramkan sebelumnya, kepemimpinan yang mengayomi ini tentunya sangat dibutuhkan. Berbincang tentang kebutuhan dalam masalah kepemimpinan, hal ini termasuk juga yang terjadi dalam bidang pendidikan, tentu saja di dalamnya membutuhkan sosok yang profesional agar dapat untuk mempengaruhi dan menggerakkan orang lain (Srinadila, 2019).

Jangan sampai dengan kepemimpinan ini justru digunakan untuk hal-hal yang tidak semestinya. Seperti yang pernah terjadi di sebuah sekolah di Kecamatan Reok, Kabupaten Manggarai, Provinsi Nusa Tenggara Timur (NTT). Di mana ada kepala sekolah dan bendahara sekolah yang ditetapkan sebagai tersangka karena tindak pidana kasus korupsi dana bantuan operasional sekolah (BOS). Tidak tanggungtanggung, pimpinan lembaga pendidikan tersebut melakukan tindak kriminal lebih dari sekali. Mereka menggelapkan dana BOS dari tahun 2017, 2018, 2019 dan 2020 dengan total uang senilai 839 juta rupiah (Kompas.com, 2021).

Dalam hal lembaga pendidikan, agar tujuan dan harapan yang hendak dicapai dapat dilaksanakan secara bersama-sama oleh warga lembaga pendidikan atau sekolah tersebut, orang lain yang harus dipengaruhi dan digerakkan itu tentu saja adalah pendidik dan tenaga kependidikan di lembaga pendidikan tersebut. Karena salah satu faktor penting keberhasilan sebuah sekolah untuk mencapai tujuannya adalah terletak dari kepala sekolahnya (Fatonah, 2013). Maka sudah menjadi keniscayaan bahwa seorang pemimpin harus mempunyai sifat-sifat kepemimpinan yang memadai. Banyak teori yang mengemukakan tentang sifat-sifat kepemimpinan, salah satunya ada dalam nilai-nilai ajaran agama Islam. Dalam perspektif nilai-nilai ajaran Islam, kepemimpinan telah dicontohkan oleh para Nabi pada umumnya yang diutus Allah SWT, maupun khususnya Nabi Muhammad SAW secara sangat sempurna. Menurut KH. Muhyiddin Abdussomad sebagai utusan Allah SWT para nabi dan rasul adalah manusia pilihan yang dibekali dengan keistimewaaan-keistimewaan yang tidak dimiliki oleh makhluk Allah SWT yang lain. Mereka juga diberikan dengan sifat-sifat kesempurnaan sebagai penguat atas risalah yang dibawa. Sebagai 
kesempurnaan dari risalah yang disampaikan, Allah SWT menganugerahkan empat sifat kesempurnaan pula kepada para utusan-Nya. Empat sifat penting para Nabi tersebut yaitu: sidiq, amanah, tabligh, dan fathanah. Idealnya seorang pemimpin termasuk dalam dunia pendidikan dapat mengimplementasikan sifat-sifat kepribadian nabi tersebut (Abdussomad, 2009).

Penelitian Agam Hyansantang Maulana (2019) memberikan kesimpulan bahwa setelah kepala MI Muhammadiyah Jogoroto menerapkan kepemimpinan profetik, warga madrasah menanggapi mengenai kepemimpinan kepala madrasah tersebut. Mereka sangat setuju atas kepemimpinan profetik Islam yang diterapkan kepala madrasah dalam memimpin MI Muhammadiyah Jogoroto. Menurut mereka, kepemimpinan yang diterapkan kepala madrasah tersebut merupakan suatu suri tauladan dari Rasul yang dapat ditiru dan dicontoh oleh para warga madrasah yang lain dalam melaksanakan tugas-tugas keseharian di madrasah (Maulana, 2019).

Hampir senada dengan penelitian sebelumnya, hasil penelitian Ahmad Anwar (2017) juga menunjukkan bahwa kepemimpinan profetik Islam tersebut merupakan salah satu alternatif model kepemimpinan yang dapat diterapkan di perpustakaan. Di mana model kepemimpinan ini bisa dijalankan untuk merumuskan visi misi perpustakaan yang kemudian diikuti oleh semua bawahan, menyusun rencana strategis perpustakaan yang melibatkan bawahannya, dan dapat mengaplikasikannya dalam penyusunan program-program kerja yang akan dilakukan di perpustakaan (Anwar, 2017).

Dengan demikian, implementasi sifat nabi merupakan salah satu hal yang penting untuk diterapkan dalam kepemimpinan pendidikan. Karena sebagai pemimpin, tentu keteladanan sangat dibutuhkan oleh para bawahan atau orang-orang yang dipimpinnya. Di lembaga pendidikan, orang-orang yang dipimpin yaitu para guru dan karyawan. SD Muhammadiyah Imam Syuhodo Sukoharjo merupakan sekolah Islam di bawah naungan Persyarikatan Muhammadiyah yang pengelolaannya sarat dengan penanaman nilai-nilai Islam. Selain menanamkan nilai-nilai Islam bagi para siswanya, sekolah ini juga berusaha menerapkan nilai-nilai kepemimpinan Islam. Di sini model kepemimpinan yang dijalankan adalah kepemimpinan secara Islam dengan berbasis sifat-sifat nabi, meskipun dikelola dengan manajemen sekolah modern. Maka penelitian ini bertujuan untuk mengetahui implementasi sifat nabi dalam kepemimpinan pendidikan di sekolah dasar.

\section{METODE}

Metode penelitian yang digunakan dalam tulisan ini adalah jenis penelitian kualitatif. Alasan pemilihan jenis penelitian kualitatif dalam tulisan ini karena pemahaman secara mendalam terhadap suatu masalah dalam metode penelitian kualitatif lebih ditekankan daripada melihat permasalahan untuk penelitian generalisasi (Siyoto, 2015). Penelitian ini dilakukan di SD Muhammadiyah Imam Syuhodo Sukoharjo. Alasan pemilihan tempat penelitian karena sekolah dasar ini dikenal di masyarakat sebagai sekolah yang bercirikan nilai-nilai Islam. Narasumber penelitian ini adalah kepala sekolah, guru, karyawan dan orang tua siswa. Teknik pengumpulan data pada penelitian ini menggunakan wawancara, observasi, dan dokumentasi. Sedangkan alat pengumpulan data adalah pedoman wawancara dan pedoman observasi.

Dalam penelitian ini pemeriksaan validitas data dilakukan dengan teknik triangulasi yang mengacu pada Moleong yang memberi pengertian teknik triangulasi yaitu teknik pemeriksaan keabsahan data dengan cara memanfaatkan sesuatu yang lain di luar data itu untuk keperluan pengecekan atau pembanding terhadap data itu. Tujuan teknik triangulasi adalah mengecek kebenaran data tertentu dengan membandingkan dengan data yang diperoleh dari sumber lain (Moleong, 2006). 
Analisis data yang digunakan dalam penelitian ini adalah analisis diskriptif interaktif Milles Huberman. Model analisis interaktif (interactive model of analysis) adalah model analisis dimana antara ketiga komponennya (data reduction, data display, conclusion drawing) memiliki aktivitas berbentuk interaksi dengan proses pengumpulan data berbagai proses siklus.

\section{HASIL DAN PEMBAHASAN}

Dari penelitian ini diperoleh hasil bahwa Kepala Sekolah sudah berusaha untuk mengimplementasikan sifat-sifat nabi dalam menjalankan kepemimpinan di SD Muhammadiyah Imam Syuhodo. Sebagaimana sekolah-sekolah lain yang mempunyai kekhasan yang dijalankan di sekolahnya tersebut, SD Muhammadiyah Imam Syuhodo juga mempunyai kekhasan tersendiri. Salah satu kekhasan sekolah ini adalah dengan penerapan nilai-nilai keislaman dalam kesehariannya. Dalam penerapan nilai-nilai Islam tersebut, kepala sekolah juga berusaha untuk menjalankan kepemimpinan berdasarkan apa yang telah diteladankan para nabi, khususnya Nabi Muhammad dalam sifat-sifatnya. Empat sifat penting yang juga disebut dengan sifat wajib para nabi tersebut yaitu: sidiq, amanah, tabligh, dan fathanah (Nasukah, 2020). Sidiq berarti jujur atau dapat dipercaya (Musyrifin, 2020). Amanah bermakna dapat bertanggung jawab dengan apa yang ditugaskan (Luthfi, 2019). Tabligh bisa dimaknai dengan komunikatif atau bisa berkomunikasi dengan efektif (Amalia, 2015). Dan fathanah yang artinya cerdas (Tyas, 2019). Menurut Kepala SD Muhammadiyah Imam Syuhodo Ustadz Giyarto, S.Pd.I keempat unsur ini harus ada dalam setiap manusia yang di pundaknya memikul kepemimpinan, termasuk di dalamnya kepemimpinan di bidang pendidikan. Karenanya dirinya juga berusaha semaksimal mungkin agar keempat sifat nabi tersebut dapat dia jalankan selaku kepala sekolah.

\section{Sidiq (jujur)}

Dalam wawancara dengan Kepala SD Muhammadiyah Imam Syuhodo mengenai makna sidiq Giyarto mengatakan bahwa sifat sidiq ini merupakan sifat yang dapat diindikasikan dengan menyampaikan kebenaran kepada orang lain seutuhnya tanpa diada-adakan dan dibuat-buat. Salah satu guru SD Muhammadiyah Imam Syuhodo Rahmawanto mengartikan sidiq sebagai benar, jujur atau integritas. Dalam istilah yang lain hal ini disebut sebagai sebuah kejujuran yang murni. Kejujuran yang tidak hanya ditampakkan kepada orang lain saja, tetapi lebih dari itu, kejujuran tersebut juga dilakukan kepada diri sendiri. Karena jika orang sudah bisa jujur kepada diri sendiri, maka dia akan lebih bisa jujur pula kepada orang lain (Fadhli, 2018). Muara dari sifat jujur ini tidak lain dan tidak bukan adalah karena adanya ketauhidan yang lurus kepada Tuhan dalam diri seseorang (Luthfi, 2019).

Giyarto mengatakan di antara bentuk kejujuran yang sudah dilakukan di SD Muhammadiyah Imam Syuhodo adalah kegiatan evaluasi rutin asatidzah (dewan guru). Evaluasi rutin dewan guru ini menilai masing-masing pribadi guru dengan kebenaran dan kejujuran. Guru mengevaluasi diri mereka sendiri sesuai dengan kejujuran yang dimiliki masing masing. Dalam kegiatan ini kedisiplinan dan sikap yang kurang pas dalam kesehariannya sebagai guru mereka disampaikan berdasarkan data dan fakta yang ada. Semuanya disampaikan apa adanya dan tidak menyampaikan hal yang bukan menjadi kenyataan. Saat dievaluasi tersebut, masing-masing guru juga harus menyadari sendiri atas kebenaran yang terjadi tersebut. Guru satu dengan yang yang lain juga dapat saling memberikan nasihat. Dan semuanya dilakukan semata-mata karena kejujuran.

Dalam penerapan sifat sidiq ini, Kepala Sekolah menyampaikan ada kendala yang dihadapi. Di antaranya ketika ada ketidakdisiplinan yang dilakukan oleh seorang guru senior. Saat hal ini terjadi, terkadang ada rasa sungkan saat akan menyampaikan kebenaran dengan jujur kepada yang lebih senior tersebut. Apalagi 
jika guru tersebut juga lebih senior dari kepala sekolah. Meskipun begitu kepala sekolah juga tetap menyampaikan kebenaran kepada guru yang bersangkutan dengan tetap memperhatikan norma dan etika seorang yang muda kepada seorang yang lebih tua. Misalnya dengan cara mengajak guru yang bersangkutan berdiskusi pada waktu-waktu yang santai. Sehingga guru yang lebih tua tersebut tetap bisa menerima kebenaran yang disampaikan oleh kepala sekolah tanpa merasa dihakimi.

Menurut Rahmawanto sifat sidiq sudah dilaksanakan di sekolahnya. Seperti dalam bersikap, disiplin, dan etos kerja yang baik, sudah banyak dicontohkan oleh pimpinan sekolah. Berikutnya dalam hal pembiasaan amalan Islami. Pimpinan menanamkan bahwa berada di sekolah ini tidak hanya sebagai tempat bekerja, tetapi juga bisa mendapatkan manfaat yang lebih utama, yaitu sebagai tempat yang mendukung penuh untuk membangun kualitas spiritual diri dengan nilai-nilai Islam, juga dalam rangka mencari pahala. Di antara kendala penerapan sifat sidiq ini menurut Rahmawanto adalah kurangnya keistiqamahan atau konsistensi. Serta kurangnya keberanian untuk menunjukkan jika seperti ini benar, seperti ini kurang tepat, serta bagaimana yang seharusnya dilakukan. Mekipun pimpinan sudah memberikan contoh, dalam beberapa kesempatan penerapannya masih tidak seperti yang dicontohkan atau tidak diikuti dengan baik.

Dalam perspektif orang tua/wali siswa, menurut salah satu orang tua siswa kelas 3 SD Muhammadiyah Imam Syuhodo Andika Rahmawan, sifat sidiq ini sudah diterapkan oleh sekolah di antaranya dengan mengajarkan anak untuk senantiasa berkata jujur, tidak berbohong dalam setiap perkataan dan tingkah laku. Menurutnya di antara kendala penerapan sifat sidiq ini kadang justru datang dari luar sekolah, seperti lingkungan bermain di rumah, media HP atau TV yang mengajarkan anak untuk tidak jujur.

\section{Amanah (tanggung jawab)}

Salah satu guru SD Muhammadiyah Imam Syuhodo Ainur Rohmah mengartikan amanah ini dengan dapat dipercaya. Sedangkan salah satu orang tua/wali siswa kelas 6 Ninin Karlina memaknainya dengan sebuah kepercayaan dan tanggungjawab. Karyawan sekolah Megawati Kharisma Dewi melengkapi arti amanah tersebut dengan melaksanakan suatu tugas pada tempatnya. Kepala SD Muhammadiyah Imam Syuhodo Giyarto mengartikan sifat amanah ini dengan menjalankan tugas yang diberikan dengan sebaik-baiknya dan penuh tanggung jawab. Amanah yang diembannya adalah amanah yang berat. Menurutnya, dia telah diberikan kepercayaan atau tanggung jawab oleh banyak pihak, oleh Dinas Pendidikan dia diberi tanggung jawab sebagai guru yang bertugas untuk mencerdaskan anak bangsa. Oleh Pimpinan Cabang Muhammadiyah Blimbing selaku yayasan pemilik sekolah dia diberikan tanggung jawab sebagai pemimpin atas rekan-rekannya dan peserta didik di sekolah. Oleh orang tua/wali siswa dia diberikan tanggung jawab untuk mengelola anak-anaknya agar kelak menjadi anakanak yang sesuai dengan harapan para orang tua tersebut. Dan yang pasti dia yakini bahwa semua tanggung jawab tadi juga diberikan kepadanya oleh Tuhan yang Mahaesa, Allah SWT (Sakdiyah, 2016). Karena baik amanah dari negara, yayasan maupun orang tua tersebut pada hakikatnya juga akan dipertanggungjawabkan di hadapan Allah SWT kelak di akhirat nanti.

Maka Kepala Sekolah pun juga berusaha untuk menjalankan amanah yang diberikan yayasan tersebut dengan melaksanakannya sesuai tupoksi, selalu berusaha memberikan yang terbaik. Dirinya sekuat tenaga berusaha untuk tidak menyelewengkan jabatan yang diembannya dengan mengambil keuntungan pribadi yang justru dalam waktu yang bersamaan dapat merugikan bagi sekolah. Menjaga nama baik diri sendiri dan sekolah adalah amanah tidak hanya diberikan oleh 
yayasan, tapi juga oleh orang tua siswa. Menurut Permendikbud nomor 6 tahun 2018, tugas pokok kepala sekolah adalah manajerial, pengembangan kewirausahaan dan supervisi akademik (Permendikbud No 6, 2018).

Salah satu tanggung jawab yang diberikan kepada seorang kepala sekolah adalah mengelola dana pendidikan, baik dana itu adalah yang diterimanya dari pungutan/sumbangan orang tua/wali siswa, maupun bantuan/hibah dari pemerintah berupa bantuan operasional sekolah (BOS) atau alokasi dana hibah yang lainnya. Termasuk ada juga dana sumbangan atau donasi dari masyarakat secara umum. Menghadapi hal ini kepala sekolah selalu berusaha untuk transparan dalam penggunaan dana-dana tersebut. Laporan keuangan selalu disampaikan secara rutin, baik kepada Dinas Pendidikan, yayasan, maupun orangtua. Bayangkan jika seorang yang telah diamanahi jabatan kepala sekolah menjadi orang yang tidak amanah, maka yang terjadi adalah penyelewangan dana tersebut. Dan tentu hal ini akan membawa kerugian untuk orang banyak. Dan hal itu tidak diinginkan oleh semua orang, termasuk oleh Kepala SD Muhammadiyah Imam Syuhodo.

Selain itu sekolah juga menerapkan pembagian tanggung jawab sesuai dengan kualifikasi dan kapasitasnya masing-masing. Pembagian tanggung jawab ini sangat penting karena dapat memaksimalkan potensi masing-masing personal dalam melakukan pekerjaannya. Jika sumber daya manusia yang ada dapat dioptimalkan, maka arah dan tujuan sekolah pun dapat dicapai dengan maksimal. Karena setiap pekerjaan sudah ada motor penggeraknya masing-masing (Entrinasari, 2020).

Dalam penerapan sifat amanah ini kepala sekolah juga memiliki kendala, di antaranya adalah naik turunnya semangat dalam menjalankan amanah. Maka dia pun mencoba untuk selalu memperbaiki diri dan mengevalusi amanah yang diberikan kepadanya tersebut. Menghadapi situasi yang berat sebagai kepala sekolah, bahkan terkadang ada keinginan untuk berhenti saja dari amanah sebagai kepala sekolah tersebut. Namun dirinya tidak pernah berputus asa. Kepala SD Muhammadiyah Imam Syuhodo selalu mendapatkan semangat baru dalam menjalankan amanah dari orang-orang di sekitarnya, baik oleh koleganya sesama kepala di sekolah yang lain, maupun oleh pihak-pihak lain. Dirinya juga menyadari bahwa tidak sepantasnya dirnya sebagai kepala sekolah berputus asa dari tanggung jawab yang dipikulnya, karena ia justru bertugas untuk memotivasi orangorang yang dipimpinnya, baik itu guru dan karyawan maupun siswa siswi di sekolahnya.

Menurut Ainur Rohmah sejauh ini SD Muhammadiyah Imam Syuhodo sudah berusaha untuk melaksanakan sifat amanah ini. Jika orang tua sudah mempercayakan anaknya untuk dididik di SD Muhammadiyah Imam Syuhodo berarti ini adalah bentuk amanah yang diberikan oleh orang tua kepada sekolah agar sekolah bisa mendidik siswa tersebut dengan sebaik-baiknya. Apalagi SD Muhammadiyah Imam Syuhodo adalah sekolah berbasis Islam, maka guru dituntut tidak hanya memberikan ilmu pengetahuan semata tapi juga mengajarkan ilmu agama. Menurutnya di antara kendala dari penerapan sifat amanah ini adalah masih adanya guru yang terkadang tidak menggunakan waktu sesuai jadwalnya, artinya dia tidak amanah terhadap waktu yang telah ditetapkan.

Karyawan sekolah Megawati Kharisma Dewi mengatakan bahwa sekolah sudah berusaha sekuat tenaga untuk menjaga amanah yang paling berharga dari orang tua yakni anak. Karena orang tua sudah mempercayakan/menitipkan anaknya sebagai siswa fullday school di SD Muhammadiyah Imam Syuhodo dari pagi sampai sore dengan harapan anaknya menjadi anak yang shalih/shalihah, mempunyai bekal agama yang kuat dan dapat menghafal Al Qur'an. Pengakuan karyawan sekolah ini diaminkan oleh Ninin Karlina selaku orang tua siswa yang mengatakan bahwa SD Muhammadiyah Imam Syuhodo sudah amanah. Berkaitan dengan amanah ini jika dimisalkan ada 100 poin maka dirinya akan memberikan poin 95 
untuk sekolah. Aplikasinya adalah amanah dalam mendidik dan membentuk karakter siswa. Apalagi dirinya yang sangat merasakan hal ini karena anaknya sudah duduk di kelas 6 . Angka 5 sisa dari aplikasi amanah tadi dimasukkan olehnya ke dalam kendala. Menurutnya sumber daya pendidik di sekolah ini dirasa masih kurang sehingga menjadikan beberapa kasus kurang terdeteksi, contoh sederhananya masih ada sedikit kasus bullying.

\section{Tabligh (komunikatif)}

Secara bahasa tabligh dapat diartikan dengan menyampaikan. Guru SD Muhammadiyah Imam Syuhodo Ariyadi mengartikannya dengan menyampaikan ilmu agama yang sesuai dengan Al Qur'an dan Sunnah, yang mana para nabi dan rasul dulu menyampaikan perintah Allah SWT dengan fasih dan bahasa yang mudah diterima orang. Salah satu wali murid kelas 3 Hamidah mengartikannya dengan menyampaikan suatu perkara yang baik kepada orang lain. Maka sebagai kepala sekolah harus bisa menjadi seorang yang dapat selalu menyampaikan sesuatu yg baik, entah di sekolah, di keluarga maupun di tengah masyarakat. Tabligh dalam Islam yang juga dapat diartikan dengan dakwah juga sudah dilakukan oleh kepala sekolah. Giyarto selain menjabat sebagai Kepala Sekolah SD Muhammadiyah Imam Syuhodo juga aktif di masyarakat sebagai anggota Korps Mubaligh Muhammadiyah (KMM). Dirinya merupakan pengisi kajian pekanan keliling di 100 masjid di wilayah Kecamatan Polokarto Kabupaten Sukoharjo. Dalam implementasi tabligh ini pada kegiatan sekolah, dirinya juga memprogramkan adanya kajian bulanan untuk dewan guru di sekolahnya.

Tabligh ini juga diwujudkan dalam kegiatan SD Muhammadiyah Imam Syuhodo dengan tajuk "kepedulianku" (Penyusun, 2018). Kegiatan ini diikuti guru dan siswa dalam bentuk semangat peduli dan berbagi kepada masyarakat. Baik masyarakat di sekitaran lingkungan sekolah, maupun masyarakat di daerah pinggiran yang dinilai membutuhkan. Di antara bentuk kegiatan kepedulianku ini adalah melalui program pembagian daging qurban saat hari raya Iduladha. Kambing yang dibeli dengan uang iuran siswa tersebut biasanya dibagikan oleh para guru sekolah tersebut dalam bentuk hewan hidup di daerah-daerah minoritas muslim yang masih jarang ada orang berqurban di sana. Selain itu ada juga kegiatan santunan yang dilakukan langsung oleh para siswa, yaitu: pertama, kelas 1-2 biasanya dilakukan di desadesa sekitar sekolah melalui kerjasama dengan Pimpinan Ranting Muhammadiyah setempat. Sasaran dari kegiatan ini adalah anak-anak seusia TK, baik yatim atau dhuafa; kedua, kelas 3-4, kunjungan di panti asuhan; dan ketiga, kelas 5-6 , dilakukan melalui kunjungan di panti jompo dan yayasan difabel.

Kegiatan tabligh juga diterapkan untuk siswa dengan bentuk pengabdian kepada masyarakat. Yaitu dalam kegiatan sekolah yang diberi nama "home stay" (Penyusun, 2019). Kegiatan ini berupa penugasan kepada siswa kelas 6 untuk tinggal di rumah-rumah penduduk yang ditunjuk. Di mana siswa harus menunjukkan budi pekerti dan karakter yang baik kepada tuan rumah dan tetangga sekitarnya. Selain itu siswa harus beraktifitas sebagaimana aktifitas tuan rumah, entah berkebun, bertani, beternak dan sebagainya. Selain melatih kemandirian siswa, hal ini juga sebagai bentuk tabligh juga, yaitu mempromosikan sekolah di masyarakat dengan siswa siswi sebagai dutanya. Sekolah juga menjadikan guru dan karyawan sebagai duta sekolah di tengah-tengah masyarakat. Artinya, guru dan karyawan harus aktif dalam kegiatan kemasyarakatan di sekitar lingkungan tempat tinggalnya masing-masing dan menjadi teladan dalam kebaikan di masyarakat.

Menurut Ariyadi sifat tabligh ini sudah dilaksanakan di SD Muhammadiyah Imam Syuhodo. Sudah banyak ilmu yang diberikan oleh guru kepada para siswanya. Sejak awal kelas 1 siswa sudah diajarkan tentang adab-adab dan kebiasaan Islami yang Rasullullah SAW ajarkan, di antaranya: adab tentang makan dengan diawali 
doa, duduk, mengambil dari yang dekat, serta menggunakan tangan kanan; adab beribadah dari cara wudhu, shalat serta bacaannya, dzikir doa yang benar, bahkan adab masuk masjid dan keluar masjid menggunakan kaki apa serta doanya; adab bicara (sopan santun) kepada orang tua, teman dan orang lain, sampai berkata yang jujur dan benar; adab menyayangi dan tidak menyakiti ciptaan Allah SWT; dan masih ada adab-adab yang lain-lain. Saat siswa sudah beranjak remaja, yaitu yang duduk di kelas atas, sifat tabligh ini bahkan sudah mereka kuasai, mereka bahkan sudah bisa memberikan contoh kepada adik-adik kelasnya.

Orang tua pun mengiyakan apa yang disampaikan Ariyadi tersebut. Hamidah menyampaikan bahwa menurutnya secara umum sekolah sudah menerapkan sifat tabligh ini di sekolah, karena SD merupakan lembaga pendidikan yang otomatis mendidik para siswanya dengan menyampaikan ilmu, secara khusus menyampaikan bagaimana menjadi siswa yang memiliki karakter takwa, dengan praktik ibadah, menanamkan sifat terpuji pada kepada anak, mengajarkan adab.

Kalau hal-hal di atas semuanya berkaitan dengan tabligh secara makna dakwah dalam Islam maupun secara kemanusiaan dan sosial, maka SD Muhammadiyah Imam Syuhodo juga mewujudkan semangat tabligh ini dalam bentuk kegiatan kehumasan sekolah. Di mana sekolah mengelola berbagai media sosial agar kegiatan sekolah dapat diketahui secara luas oleh masyarakat, selain website resmi, sekolah juga mengelola facebook, instagram dan kanal youtube. Tabligh juga dilaksanakan oleh kepala sekolah dalam bentuk musyawarah atau rapat rutin sekolah. Sekolah sendiri mempunyai beberapa rapat rutin, yaitu pekanan, bulanan, semesteran dan tahunan. Selain itu, ada juga musyawarah yang digelar dalam waktu-waktu insidental di mana waktu tersebut mendesak untuk dilaksanakan musyawarah.

Di antara kendala implementasi tabligh ini menurut kepala sekolah adalah masih terbatasnya ilmu yang dimiliki oleh pimpinan maupun pengelola sekolah yang lain. Meski demikian, sekolah terus menggalakkan kepada guru dan karyawan agar dapat menjadi humas yang ideal di masyarakat, yaitu dengan akhlakul karimah yang dimilikinya. Dari sudut pandang orang tua siswa menurut Hamidah kendala penerapan sifat tabligh ini yang ada biasanya berasal dari peer group/kelompok teman sebaya. Ketika ada pengaruh yg tidak baik dari satu siswa ke siswa yang lain maka penerapan tabligh menjadi tidak maksimal.

\section{Fatanah (cerdas)}

Guru SD Muhammadiyah Imam Syuhodo Sri Jono Listiyanto memaknai sifat fathanah ini dengan memiliki kecerdasan yang tinggi. Sedangkan Lina Sugiarti salah satu wali siswa melengkapi makna cerdas dalam fathanah ini dengan bijaksana. Sifat ini diterapkan di SD Muhammadiyah Imam Syuhodo di antaranya berkaitan dengan kualifikasi guru dan karyawan (Daftar Guru Dan Karyawan SD Muhammadiyah Imam Syuhodo Tahun 2020/2021, 2020). Di mana guru dan karyawan SD Muhammadiyah Imam Syuhodo dituntut agar secara keilmuan mampu untuk mendidik siswa siswi di sekolah tersebut. Gambaran data guru selengkapnya dapat dibaca dalam tabel berikut:

Tabel 1. Kualifikasi Guru di SD Muhammadiyah Imam Syuhodo

\begin{tabular}{|ccc|}
\hline $\begin{array}{c}\text { Pendidikan } \\
\text { Terakhir }\end{array}$ & Jumlah & $\begin{array}{c}\% \text { total } \\
\text { guru }\end{array}$ \\
\hline S1 & 16 & 55.17 \\
\hline D1 & 1 & 3.45 \\
\hline
\end{tabular}




\begin{tabular}{|lll|}
\hline SMA sederajat & 12 & 41.38 \\
\hline & 29 \\
\hline
\end{tabular}

Tabel di atas menunjukkan bahwa dari 29 guru dan karyawan SD Muhammadiyah Imam Syuhodo, 16 di antaranya sudah menyandang gelar sarjana, 12 di antaranya lulusan SMA atau yang sederajat, dan sisanya lulusan D1. Dari 12 lulusan SMA sederajat dan 1 lulusan D1 ini masih ada 5 yang saat ini sedang menempuh kuliah S1. Tabel di bawah ini menjelaskannya:

Tabel 2. Guru SD Muhammadiyah Imam Syuhodo yang Sedang Kuliah S1

\begin{tabular}{|ccc|}
\hline Guru & Jumlah & $\begin{array}{c}\text { \% jumlah } \\
\text { guru }\end{array}$ \\
\hline Sedang kuliah S1 & 5 & 38.46 \\
\hline Tidak/belum kuliah S1 & 8 & 61.54 \\
\hline & 13 & \\
\hline
\end{tabular}

Jika masih terdapat banyak guru yang belum lulus $\mathrm{S} 1$, lantas bagaimana dengan kapabilitas guru tersebut? Kepala sekolah ternyata juga tidak tinggal diam. Selain terus mendorong para guru agar menempuh dan menyelesaikan pendidikan sarjana, sekolah juga secara rutin melakukan upgrading internal guru setiap pekan. Dalam kegiatan upgrading ini guru dan karyawan dibekali dengan ilmu-ilmu kepandidikan baik terori maupun praktik. Guru juga dimunta untuk melakukan micro teaching dengan objek rekan-rekan gurunya masing-masing. Di sini guru yang satu dengan yang lain dapat saling melengkapi jika ada kekurangan satu sama lainnya.

Selain itu, sekolah juga secara ruting menggelar in house training (IHT) setiap satu semester sekali. Kegiatan in house training ini biasanya diadakan saat liburan semester, sepekan sebelum siswa masuk sekolah, guru-guru sudah diwajibkan untuk masuk dan mengikuti serangkaian IHT yang diselenggarkan sekolah. Kegiatan ini disi oleh orang-orang yang berkompeten di bidang pendidikan, baik oleh praktisi pendidikan di sekolah lain, dari pengurus persyarikatan Muhammadiyah, dari dinas pendidikan, maupun akademisi dari kampus-kampus. Selain in house training internal, sekolah juga rutin mengirimkan guru-gurunya dalam kegiatan workshop yang diselenggarakan oleh dinas pendidikan. Menurut kepala sekolah, kegiatan IHT maupun workshop ini bertujuan untuk merefresh wawasan keilmuan para guru dan karyawan, juga untuk mendapatkan wawasan maupun motivasi baru dari para ahli di bidang pendidikan.

Selain IHT dan workshop, sekolah juga melakukan pembiasaan literasi/membaca kepada para guru. Karena buku adalah jendela ilmu, perpustakaan sekolah menyediakan buku yang tidak hanya bisa dibaca oleh para siswa saja, tetapi juga buku-buku yang bisa dibaca oleh pada guru dan menambah wawasan keilmuan mereka.

Menurut Sri Jono Listiyanto, terkait dengan sifat fathanah ini guru dalam hal melihat masalah dari berbagai sudut pandang dan usaha untuk menyelesaikannya dengan cepat dan tepat. Dalam konteks guru, fathanah harus bisa memberikan pendidikan bukan hanya pengajaran kepada siswa. Menurutnya di SD Muhammadiyah Imam Syuhodo, sifat fathanah ini mungkin dapat diistilahkan dengan salah kata motto sekolah yaitu "Kreatif" (Kurikulum, 2020). Sifat fathanah yg dilaksanakan di SD Muhammadiyah Imam Syuhodo khususnya berkaitan pembelajaran dengan motto 
"kreatif" ini sebagian sudah dilaksanakan di sekolah sebagai wujud berusaha mencapai visi misi sekolah. Bentuknya, misalkan di kelas 6 proses pembelajaran tematik yang seharusnya dihandel guru kelasnya sendiri dalam sehari untuk satu kali pembelajaran. Sekolah selalu melaksanakan musyawarah dengan semua guru tiap paralel kelas (kelas 6A dan 6B), dan diubah menjadi pembelajaran berdasar mupel (muatan pembelajaran). Dari situ guru yang awalnya harus mengajar dan menguasai semua mupel sehari di kelas tertentu menjadi terfokus hanya beberapa mupel yang paling dikuasainya. Diharapkan dari situ, output ilmu yang diterima santri di kelas A dan B sama berkaitan dengan mupel yang diajarkan oleh guru.

Kendala penerapan sifat fathanah ini menurut kepala sekolah adalah naik dan turunnya keistiqamahan atau konsistensi guru dalam belajar. Terkadang semagat guru dalam belajar ini naik, terkadang dalam waktu-waktu tertentu juga melemah atau menurun. Hal yang sama juga disampaikan oleh Sri Jono Listiyanto yang mengatakan bahwa kendala penerapan sifat fathanah ini di SD Muhammadiyah Imam Syuhodo berkaitan tentang SDM dari guru-gurunya. Untuk bisa melaksanakan sifat itu tentunya tidak semua sama kemampuannya. Harus ada kemauan untuk terus belajar dari tiap guru seperti banyak membaca maupun bentuk literasi lain yang nantinya meningkatkan profesionalisme guru dan ditunjang pula dari tugas sekolah untuk mensejahterakan para guru. Dari sudut pandang orang tua siswa menurut Lina Sugiarti fathanah ini sudah dilaksanakan sekolah dalam membentuk kecerdasan intelektual, emosional dan spiritual anak didik. Kendala penerapan sifat ini menurut orang tua siswa adalah karakter dan kemampuan anak yang berbeda-beda, juga semangat atau mood anak yg naik turun.

\section{SIMPULAN}

Hasil penelitian ini membuktikan bahwa kepemimpinan pendidikan oleh Kepala SD Muhammadiyah Imam Syuhodo sudah berusaha untuk menerapkan nilai-nilai Islam yang berbasis sifat-sifat kepribadian nabi. Empat sifat wajib para nabi tersebut yaitu: (1) Sidiq berarti jujur atau dapat dipercaya. Sidiq telah diimplementasikan sekolah di anataranya dalam evaluasi dewan guru dan transparansi pengelolaan keuangan; (2) Amanah bermakna dapat bertanggung jawab dengan apa yang ditugaskan. Amanah telah diwujudkan sekolah dalam rasa tanggung jawab yang besar yang dimiliki oleh guru dalam menjalankan tugas; (3) Tabligh bisa dimaknai dengan komunikatif atau bisa berkomunikasi dengan efektif. Tabligh ini telah dilaksanakan sekolah dalam bentuk dakwah Islam, kemanusiaan, musyawarah dan peran-peran kehumasan sekolah; Dan (4) fathanah yang artinya cerdas. Fathanah yang diterapkan kepala SD Muhammadiyah Imam Syuhodo di sekolahnya yaitu dalam bentuk penugasan guru sesuai kualifikasi, upgrade kemampuan guru, serta menumbuhkan budaya literasi di sekolah oleh masing-masing guru.

Menurut hasil penelitian ini memang sifat-sifat kepribadian nabi sudah dilaksanakan oleh kepala sekolah dalam memimpin sekolahnya. Namun demikian perlu juga digali lebih jauh bagaimana tanggapan warga sekolah, baik itu guru dan karyawan, siswa, maupun orang tua mengenai penerapan sifat nabi ini oleh guru atau siswa di sekolah tersebut. Maka peneliti merekomendasikan agar penelitian selanjutnya bisa mengambil subyek yang berbeda meskipun masih dalam kajian yang sama.

\section{DAFTAR PUSTAKA}

Abdussomad, K. M. (2009). Aqidah Ahlus Sunnah Wal Jama'ah (M. Faishol (ed.)). Surabaya. Khalista. 
Amalia, I. (2015). Implementasi Nilai Tabligh Pada Tenaga Pengajar Dalam Proses Belajar Mengajar Di Madrasah Aliyah Negeri Mojokerto. JESTT, 2(10), 828-849.

Anwar, A. (2017). Tipe Kepemimpinan Profetik Konsep Dan Implementasinya Dalam Kepemimpinan Di Perpustakaan. Pustakaloka, 9(1), 69-82.

Bakar, D. H. Y. A. (2014). Filsafat Pendidikan Islam. Surabaya. Universitas Islam Negeri Sunan Ampel. https://doi.org/10.24252/ip.v6i2.5231

Daftar Guru dan Karyawan SD Muhammadiyah Imam Syuhodo tahun 2020/2021. (2020). SD Muhammadiyah Imam Syuhodo.

Djunaedi, A. F. (2005). Filosofi dan Etika Kepemimpinan dalam Islam. Al-Mawarid, 13(0), 54-66. http://journal.uii.ac.id/JHI/article/view/2807

Entrinasari, F. V. (2020). Implementasi strategis manajemen sumber daya manusia perspektif al-qur 'an. Insania, 25(2), 1-13.

Fadhli, M. (2018). Internalisasi Nilai-Nilai Kepemimpinan Profetik Dalam Lembaga Pendidikan Islam. At-Ta'dib: Jurnal IImiah Pendidikan Agama Islam, 10(2), 116-127.

Fatonah, I. (2013). Kepemimpinan Pendidikan. Jurnal Tarbawiyah, 10(2), 109-125.

Kompas.com. (2021). Korupsi Dana BOS Rp 839 Juta, Kepala Sekolah dan Bendahara Ditetapkan Tersangka. https://regional.kompas.com/read/2021/07/02/102739478/korupsi-Dana-Bos-Rp-839Juta-Kepala-Sekolah-Dan-Bendahara-Ditetapkan?page=all. https://regional.kompas.com/read/2021/07/02/102739478/korupsi-dana-bos-rp-839juta-kepala-sekolah-dan-bendahara-ditetapkan?page=all

Kurikulum, B. (2020). Kurikulum SD Muhammadiyah Imam Syuhodo tahun pelajaran 2020/2021. SD Muhammadiyah Imam Syuhodo.

Luthfi, M. (2019). Implementasi Kepemimpinan Profetik Di Pondok Pesantren Nurul Huda Pesanggrahan Desa Kretek Kecamatan Paguyangan Brebes. IAIN Purwokerto.

Maulana, A. H. (2019). Kepemimpinan Profetik Islam oleh Kepala madrasah. JAMP: Jurnal Adminitrasi Dan Manajemen Pendidikan, 2(1), 26-31.

Moleong, L. J. (2006). Metodologi Penelitian Kualitatif. Bandung. PT Remaja Rosdakarya.

Musyrifin, Z. (2020). Implementasi Sifat-Sifat Rasulullah Dalam Konseling Behavioral. Al Irsyad: Jurnal Bimbingan Konseling Islam, 11, 151-159.

Nasukah, B. (2020). Internalisasi Nilai-Nilai Kepemimpinan Profetik di Lembaga Pendidikan Islam. Dirāsāt: Jurnal Manajemen Dan Pendidikan Islam, 6(1), 52-68.

Penyusun, T. (2018). Grand Design Kegiatan SD Muhammadiyah Imam Syuhodo. SD Muhammadiyah Imam Syuhodo.

Penyusun, T. (2019). Program Kerja SD Muhammadiyah Imam Syuhodo tahun pelajaran 2019/2020. SD Muhammadiyah Imam Syuhodo. 
Purwanto, N. A. (2019). Kepemimpinan Pendidikan, Kepala Sekolah sebagai Manager dan Leader. Yogyakarta. Interlude.

Permendikbud No 6, Pub. L. No. 6 (2018).

Sakdiyah. (2016). Karakteristik Kepemimpinan Dalam Islam (Kajian Historis Filosofis ) Sifat-Sifat Rasulullah. Al Bayan, 22, 29-49.

Siyoto, D. S. (2015). Dasar Metodologi Penelitian. Yogyakarta. Literasi Media Publishing.

Srinadila, R. (2019). Kepemimpinan Pendidikan. 1-5. https://doi.org/10.31227/osf.io/6yqxm

Tyas, N. R. (2019). Model Kepemimpinan Pendidikan Nabi Muhammad SAW. IAIN Ponorogo. 